\title{
Press Coverage of Nigeria-South Africa Diplomatic Face-Off Over Yellow Fever Vaccination
}

\author{
K.O Nworgu, Imo State University, Nigeria \\ Umaru Pate, University Of Jos, Nigeria \\ Chukwudi Obi, Michael Okpara University Of Agriculture, Nigeria
}

\begin{abstract}
The study was Nigeria-South Africa diplomatic face off over Yellow fever Vaccination issue. The problem started when 125 Nigerians, including a Senator of the Federal Republic of Nigeria, who landed at the Oliver Tambo International Airport on March 1st, 2012 were prevented from entering the country, because they did not have the required documentation for vaccination against yellow fever. The following day 75 of them were sent home via the South African Airways while another 50 were sent home via Nigerian Airline "Arik Air" (This Day, 3rd, March, 2012). In response to the deportation of some Nigerians from South Africa, 28 South Africans were turned back at Murtala Mohamed International Airport, and another 56 illegal immigrants from South Africa were deported following day A total of four Nigerian newspapers had a combined total of 480 editions. To arrive at the number of editions to be used, as sample size, a constructed weeks study was used to draw from the 480 editions at one day interval. This amounted to 3 editions per paper per week (Monday, Wednesday and Friday). Hence, a total of 12 editions per month multiplied by four months amounted to 48 editions on the average. Also, the total sample was gotten by multiplying 48 editions by four newspaper titles which amounted to 192 editions. The purposive sampling technique was used to select the sample of stories from the editions examined. The methods for data presentation and analysis were both qualitative and quantitative analysis. Hence we made use of frequency tables and simple percentage. The study results show that the four Nigerian Newspapers namely Vanguard, This Day, The Daily Sun and The Nation published different reports such as editorials, news stories, and letters to editor on the issues. However, the papers were not unmindful of the political implication of the face-off, hence, they tried to balance national interests and African unity thereby emphasizing less on the bad relationship such incident was capable of generating among African sister states.
\end{abstract}

Keywords: Press, coverage, diplomacy, face-off, vaccination. 


\section{Background to the Study}

The media through mainstreaming and highlighting of certain events bring such issues to public knowledge and attention. Invariably, such stories published by the press become subject of public and private discussing (Rodman, 2006). The press is not only interested in reporting foreign relations but also what they report can set for agenda for public discussions and perception on such foreign policy issues.

As the purveyors of information, the press has the responsibility of acquainting the citizens with well defined national issues, inform them of their role expectations, facilitate participation through information and education; help the individual acquire the knowledge required to discharge his social obligations (Sobowale, 1989)

South- Africa - Nigeria relationship could be traced historically, from the period of Apartheid regime in South Africa. Within that period, Nigeria aligned with the frontline states to press for a multi-race democratic South Africa. Nigeria's commitment to the course came both in cash and in kind (Meredith, 2011). It should be noted that Nigeria's commitment to ending apartheid was borne out the country's desire to see independent and free African States. To this end, the country played a major role in the liberation of Southern African countries, including the Republic of South Africa and other African countries who within that period were under colonial rule.

With the independence of South Africa, came influx of migrants, from all over Africa looking for the proverbial golden fleece. However, the legacy of apartheid included a massive disparity in wealth... and almost half of all households in South Africa lived below the poverty line (Meredith 2011, Pp.654). The level of unemployment in South Africa is very high based on long years of economic and political deprivation of the black South Africans arising from apartheid and aggravated by the global economic recession.Despite the gloomy picture, Nigeria-South-Africa Trade relation remains viable, even to the a advantage of South Africa. To this effect, so many South Africa multi-national companies are making it big in Nigeria. Also Nigerian businessmen are enjoying good business relationship with their South African counterparts. It was this cordial relationship that was unsettled by the diplomatic face - off triggered by the deportation of some Nigerian businessmen by South-Africa government on the accusation of presenting fake yellow fever vaccination card. In what was termed a 
retaliatory move, Nigerian government also deported some South-African residing in the country who were termed illegal immigrants. While the drama was going, the Nigerian pre was not left out. They reported the issue and made it public.

\section{Statement of the Problem}

The questions then are: what was the role of the press in the vaccination face-off between Nigeria and South Africa? Did Nigerian press make the public understand diplomatic faceoff-between the country and South Africa? What was the nature and extent of coverage given to the face-off by Nigerian press? This study tried to examine the press coverage of the diplomatic faceoff arising from the vaccination card issue, thereby answering the above questions.

The essence of vaccination of immigrants from yellow fever and other infectious diseases is to ensure the well-being of not only the travelers but also that of the citizens of countries where the travelers are heading to. Such practice has become a norm across the global for travelers to and from all countries of the world. The Nigerian - South - Africa Yellow Fever vaccination card face - off can be seen as either an attempt at ensuring the prevention of sickness and diseases among citizens. On the other hand, it can be seen as a political weapon aimed at scoring a political point by either South Africa or Nigeria. This thinking is supported by the events and style of the deportation of the Nigerian migrants and the hasty and retaliatory nature of Nigerian government's reaction (by deporting South African termed illegal immigrants). However, there is the feeling by Nigerian citizens that Nigerian press have not over the years played active role in Nigeria's relationship with the outside world. This is against the backdrop that Nigerian press needs to provide effective coverage for the nation's foreign policy issues. Moreover, the role of the press in influencing political, social and cultural institutions is well known (Biagi, 2003). The questions then are: what was the role of the press in the vaccination face-off between Nigeria and South Africa? Did Nigerian press make the public understand diplomatic face-off-between the country and South Africa? What was the nature and extent of coverage given to the face-off by Nigerian press? This study tried to examine the press coverage of the diplomatic faceoff arising from the vaccination card issue, thereby answering the above questions. 


\section{Objective of the Study}

The main aim of this study was to know the extent Nigerian press reported the Nigeria and South Africa diplomatic face-off. This aim was achieved through the following objectives:

1. To identify the extent of Nigerian newspapers reportage on the face-off between Nigeria and South Africa;

2. Finding out the content categories on yellow fever vaccination face-off reports between Nigeria and South Africa;

3. Ascertain the story types and directionality of the coverage by Nigerian Press.

\section{Research Questions}

RQ1 What is the extent of Nigerian Press coverage of yellow fever vaccination face-off between Nigeria and South Africa?

RQ2 What are the story types and directionality of the Nigerian press coverage of the faceoff between the countries?

RQ3 What are the content categories of the yellow fever vaccination face off between the two countries?

\section{Literature Review}

\section{Introduction}

There is dissatisfaction over the years about the role of Nigerian press in Nigeria's foreign policy issues (Ibie \& Abitudu, 1989; Akinterinwa, 2010). This is against the background that Nigerian press needs to provide effective coverage of the country's foreign policies. This is because, the role of the press in influencing political, social and cultural institution is well articulated (Biagi, 2003). Since the press all over the world is saddled with the responsibility to inform and educate their readers on foreign policy issues, can Nigerian press be said to be making the public aware of the foreign policy of Nigerian government towards South Africa? This is against the backdrop that the press remains the strongest and most potent force in aggregating all different opinions in foreign policy (Iroh, 2005).

However, the extent of press support for foreign policy is largely the function of the extent to which government was able to promptly inform and convince the press on the rationale for its foreign decisions (Akinterinwa, 2010;). To this effect, some scholars have examined the 
Nigerian press coverage of national and international issues (Alozie, 2004; Dare, 1973; Nwuneli \& Udo, 1982 \& Ugboajah 1984). Also, there have been studies in the role of the press in African development (Opubor, 1985; Atwood \& Major, 1982 and Hunt; 1982). Although, each of these studies found out the relevance of the press in Nigeria's development, but non discovered the essence of press reportage of Nigeria's foreign policy initiatives.

\section{Nigerian Press in Perspective}

Also, scholars have continued to research into the role of the press in national development (D’Alessio, 2003; Reichert, Mueller \& Nitz 2003; Winifield \& Friedman 2003; Yioulas \& Segvic, 2003; Vanbelle, 2010 \& Moelle, 2010). Again, there have been studies on Nigeria's media image of world affairs (Uche, 2000); image of Africa in elite American press (Hunt 2000) and Anglo-Nigerian Press Coverage of diplomatic scandals (Uche \& Ngwumba 2000). These studies have highlighted the basic interest of press coverage of national issues.

Thus, the basic goals of the media is fact findings and fact - giving, that is the function of news operations, determining what is and saying that it is and saying that it is and saying so publicly (Opubor, 1985; P. 250). According to Momoh (1988; p.50), "the press is not only the fourth estate of this realm, it is also the only estate that owes its allegiance, ownership not withstanding to the people to whom sovereignty belongs". Hence, that give the press the liberty to comment on any issue it deemed necessary to express opinion on and on many occasions, it had agreed with Nigeria's foreign policy. While on many occasions, it had disagreed and often took a different stand on the nation's foreign policy (See restoration of diplomatic relations with Israel) (Akinterinwa, 2010; p.173).

\section{Nigerian Press and National Interest}

It is a mandate to look into the welfare and interest of Nigerians abroad by the government of Nigeria based on the concept of citizen diplomacy (Mbachu, 2009). According to Machida, (2009, P.68) "National Interest derives from a state, political culture dominant ideology, traditions, and preceding conditions". That, in fact, is the angle from which one has chosen to view the immigration and later diplomatic faceoff between Nigeria and South Africa. The fact is that the issue could have been resolved without a diplomatic row. One thing that keep cropping up during the crisis is the South Africa supposedly "ingratitude" towards Nigeria in 
spite of the contribution made by Nigeria towards the liberation struggle (Nwanze, 2008). However, some people think we need to back off from beating them over the head with our contribution every time we get into an argument. To South Africa since many countries supported their struggle should they bow in obeisance to them every morning? However, unless Nigeria strategically reviews her relationship with countries in Africa, in order to maintain good relationship with them.

Apparently, the Federal government handling of the matter may have sent out signals to other countries that Nigerian will no longer allow the right of her citizens to be violated by any country. This is based on the fact that for too long Nigerians have been subjected to all kinds of shabby treatment at airports worldwide based on negative perceptions (Ogunsanwo, 2009). For instance some Nigerians have been arrested for various crimes Nigerians have been labeled criminals, and immigration officers all over the world are usually on red alert while checking Nigerians (Maduekwe, 2009). Did Nigerian press give the issue of the diplomatic row between Nigeria and South Africa a balanced coverage? Hence, despite the increasingly presence of Nigerians in South Africa and the obvious xenophobic disposition of South African and Nigerian press is expected to promote African unity and protect national interest in the coverage of the face-off.

\section{South African - Nigeria Historical Relations}

The South Africans companies have huge investment in Nigeria and many African nations. For example, MTN has more subscribers in Nigeria than they do in South Africa. Multichoice derives an increasing proportion of its revenue from Nigeria, where again there are more DSTV subscribers than in South Africa. Same can be said for Standard bank. Many Nigeria travelers are businessmen, business partners to top South Africa companies (Business Day, 2012). Unfortunately, average South African customs and immigration officers operate under the misconception that all foreigners coming to South Africa are coming to beg, do crime or take their jobs (Nwanze, 2003). Before now, South African's economy was generally on a low growth. It was struggling to grow at more than $3 \%$ per year due to various structural issues. Much of the high growth by South African countries is to be found in the rest of Africa. Ironically, the ANC had expected to inherit an economic cornucopia, its ambitious development plans were based on that notion. But the coffers, in fact were empty 
(Meredith, 2011; P.655).

Therefore, subsidiary companies outside South Africa provide $10 \%$ of economic growth in the country. South Africa wants to maintain her status as the dominant Africa economic player. Hence, the South African government was quick to admit the fault of its officials and not allowing the diplomatic row to degenerate into a major crisis which will definitely not be in the interest of both countries.

Historically, Nigeria and South Africa are both British colonies and members of Common Wealth and African union: However following the end of apartheid in 1994, South African business men sought for skilled manpower to manage the post-apartheid fast-growing economy. This led to the migration of a large number of Nigerians professional to South Africa. Hence, it is estimated that over 24,000 Nigerians are living in South Africa in 2011. (Business Day, 2015)

Since Nigeria government was a supporter of libration efforts and anti-apartheid movement in 1970s and 1980s, a generation of Nigerians sees South Africa as a brother country, where they can live and do business. But it been alleged that since the end of apartheid, South Africa have not shown the kind of reciprocal relationship to Nigerian government and her citizens (Wole Olaoye in Daily Trust, 2013). However, to Nigerian businessmen, South Africa remains, at moment, the safest place to do business. Ironically, South Africa, businessmen are thriving in Nigeria and some South African companies are making it big in Nigeria.

\section{Nigeria -South Africa Economic Diplomatic Relations}

Policy is the articulation and implementation of a line of action by a country towards her relationship with other countries. It is the basis on which one state engages another subject to international law. Diplomacy and foreign policy are of great relevance as far as international relations is concern. Therefore, the foreign policy of any nation is usually anchored on a solid economic base, backed up with military might. But, most importantly trade and commerce are the motivating factors for relationships among countries on comparative cost advantage (Daily Sun Tuesday March, 27, 2012; .p 20). Reliably, it is expected that each country that has either bilateral, treaty, or any form of understanding aimed at treating nationals of other 
countries with respect and giving them maximum protection when required. To this effect, with above mentioned obligations which are expected of a nation to another it will be unfair for a country to deport, arrest, humiliate, execute or detain other nationals without following due process (Diplomatic Procedure). Unfortunately, an ugly incident of fake yellow fever vaccination cards led to a diplomatic face-off between Nigeria and South Africa. The Nigerian press coverage of this incident was massive; making top stories for magazines, newspapers and some on-line publications.

\section{Fake Yellow Fever Vaccination Cards: The Story}

The problem started when 125 Nigerians, including a Senator of the Federal Republic of Nigeria, who landed at the Oliver Tambo International Airport on March 1st, 2012 were prevented from entering the country, because they did not have the required documentation for vaccination against yellow fever. The following day 75 of them were sent home via the South African Airways while another 50 were sent home via Nigerian Airline "Arik Air" (This Day, 3rd, March, 2012). In response to the deportation of some Nigerians from South Africa, the then Nigeria's Foreign Affairs Minister, Gbenga Ashiru vowed to retaliate for what he termed a "disrespectful attitude" from South Africa. The minister was quoted as saying "I find the actions totally unfriendly and un-African (The Nation, March 11, 2012, p.13)

Unfortunately, in a move seen as retaliatory, 28 South Africans were turned back at Murtala Mohamed International Airport, and another 56 illegal immigrants from South Africa were deported following day (Vanguard, 6 March, 2012). Consequently, the South Africa's spokesman for International Relations and Cooperation Department, Clayson Monyela said that Nigeria was blowing things out of proportion and missing issues. "This is health matter not a diplomatic issue. Now that it's being elevated to a diplomatic level, we will deal with it". However, Clayson Monyela press briefing to clarify the matter. Also, South Africa's Home Affairs Department spokesman, Ronnie Mamoepa noted that it was standard international protocol. Hence, the public must understand that communicable disease must be controlled". Another South Africa from the Department of Health added that: "we were in line with our policies, which we do not just wake up and write, we follow WHO (World Health Organisation) guidelines. And everything was done according to the book". The spokes person said that the department has a responsibility to protect the country's border 
from the spread of diseases, (Daily Sun Newspaper, March 4th 2012).

In reaction to this statement, the then Nigerian Health Minister, Prof. Onyebuchi Chukwu, declared that none of the 125 deported Nigerians from South Africa was in possession of fake yellow fever card. He also noted that the last reported case of yellow fever in the country was in 1995 and maintained that the ministry does not have any reported case of fake yellow fever card before it from any individual or any country. Prof. Onyebuchi Chukwu also said, it is curious that a country that had issued entry visa to intending travelers which issuance was predicted on the presentation of a valid yellow card will then turn around to deport those travelers This Day, March, 7, 2012, p.8). Consequently, South African authorities tendered an unreserved apology to Nigeria, saying that it took them more than 48 hours to investigate before tendering an apology.

\section{Theoretical Framework}

This study is based on the "citizencentric" concept of Nigeria's foreign policy. The Afrocentric policy was aimed at the liberation of African countries from colonialism and oppressive rule. To this effect, Nigeria's Afrocentric diplomacy helped in achieving political independence and the liberation of most African countries. This policy was adopted immediately after Nigeria's independence in 1960. Hence, "Nigeria has pursued a foreign policy predicted largely on being her brothers' "keeper" (Maduekwe, 2009; p.7). Therefore, Afrocentricism has made it possible for a foreign policy objective that is fashioned to liberate African countries still under colonial rule and fight for the emancipation of the black man anywhere he is in the world (Maduekwe, 2009; p.9). Citizen diplomacy on the other hand, refers to the organized action that the Nigerian government takes to achieve the objectives that have been set by foreign policy members (Maduekwe, 2009; p. 63). The concept of citizen diplomacy defines Nigerian citizens as businessmen who have been bemoaned the lack of synergy that is expected in partnership between government and the private sector in any foreign policy initiative. It entails the protection of the interests of Nigerian citizens wherever they may be in the world. It allows Nigerian government to intervene where necessary whenever Nigerian citizen is been maltreated or marginalized in any foreign land. (Agbu; 2009) 
It is a citizen-centered diplomacy which allows Nigerian citizens abroad to be the centre of Nigeria's national interest. Hence, the country's diplomatic machinery is deployed towards protecting the interest of Nigerian citizens abroad. As argued by Ogunsanwo (2009, p: 19), "The protection of the interest of Nigeria's abroad is an integral part of the diplomatic functions recognized by the Vienna Convention of 1961 governing diplomatic relations".

Citizen diplomacy articulates what is or should be implicit as the major goal of Nigeria's foreign policy; being people - centered, it is a step in further saying that in both its national and international actions, "the Nigerian state will be driven primarily by the need to promote the welfare and security of every Nigeria" (Eze, 2009, P. 31). Citizen diplomacy as constructed by Nigeria under Late President Musa Yar'Adua means that Nigeria's foreign policy will henceforth be focused on the Nigerian citizens at home and in the diaspora (Agbu, 2009; P.41). It is a mandate to look into the welfare and interest of Nigerians abroad by the government of Nigeria (Mbachu 2009). It covers every issue that border on giving Nigerians the maximum protection and seeking to ensure that their welfare is not compromise in any foreign level (Eze, 2009).

It is against this backdrop that the deportation of Nigerians from South Africa over the allegation of fake yellow fever vaccine card attracted a retaliatory reaction from Nigerian government should attract the attention of the Nigerian press. "This could mean that from now on, the Nigeria citizens abroad are the centre of Nigeria's national interest and therefore the country's entire diplomatic machinery should geared towards protecting his or her interest, including economic welfare" etc (Ogunsanwo, 2009; p2). This is because the apparent or perceived criminalization of Nigerian citizens abroad is what citizen diplomacy intended to address. It is on this note that the deportation of Nigerian citizens from South Africa over yellow fever vaccine card was seen criminalizing Nigerians in that country. Hence, the federal government did embark on retaliatory measure to forestall further occurrence. On the note, Nigerian press reports on the issue were expected to tally with Nigerian government's disposition towards protecting her citizens, while at the same time promoting African unity. 


\section{Research Methods}

The total accessible population for the study was drawn from a total of the newspaper editions, published by the four national newspapers for a period of four months March 2012 June, 2012. Therefore, the four newspapers had a combined total of 480 editions. To arrive at the number of editions to be used, as sample size, a constructed weeks study was used to draw from the 480 editions at one day interval. This amounted to 3 editions per paper per week (Monday, Wednesday and Friday). Hence, a total of 12 edition per month multiplied by four months amounted to 48 editions on the average. Also, the total sample was gotten by multiplying 48 editions by four newspaper titles which amounted to 192 editions. When the content of the newspapers were examined it was discovered some had more publications on the issue than others, while on certain days there were no story on the issue by any of the newspapers. Two coders were used for coding and $92 \%$ intercoder reliability was gotten using a reconstructed formula thus:

$$
\frac{2 \mathrm{~m}}{\mathrm{~N} 1+\mathrm{N} 2}
$$

The purposive sampling technique was used to select the sample of stories from the editions examined. The methods for data presentation and analysis were both qualitative and quantitative analysis. Hence we made use of frequency tables and simple percentage.

\section{Results}

The table 1 (see appendix 1) shows that the four Nigerian Newspapers namely Vanguard, This Day, The Daily Sun and The Nation published different reports such as editorials, news stories, and letters to editor on the issues. The results shows that Vanguard had editorial 11.3, news stories $61.4 \%$, opinion article $4.55 \%$, letters to-editor $4.55 \%$ and cartoon/pictures $18.2 \%$ but had no features on the issue under review. This Day also had 6.52\% editorials, news stories $45.65 \%$, opinion article $10.87 \%$, features $26.08 \%$, letters -to- editor $2.17 \%$ and cartoons/pictures $8.70 \%$ Daily Sun had editorials $18.52 \%$ news stories $3.04 \%$, features $29.63 \%$, and letters to editor $14.8 \%$ but did not have any opinion article and cartons and pictures on the issues. The Nation newspaper had more news stories and editorials, representing $14.8 \%$ and $13.04 \%$ respectively, features $8.70 \%$, opinion article $5.80 \%$, while cartoons/pictures are $10.14 \%$. Therefore, the four Nigerian newspapers were able to report a total of $9.14 \%$ editorials, $57.69 \%$ news stories, $5.91 \%$ opinion articles $13.69 \%$ features, 
$5.38 \%$ letters to editor and $12.90 \%$ cartoons and pictures on the diplomatic face-off.

Pie - Chart showing nature of stories published on the face-off

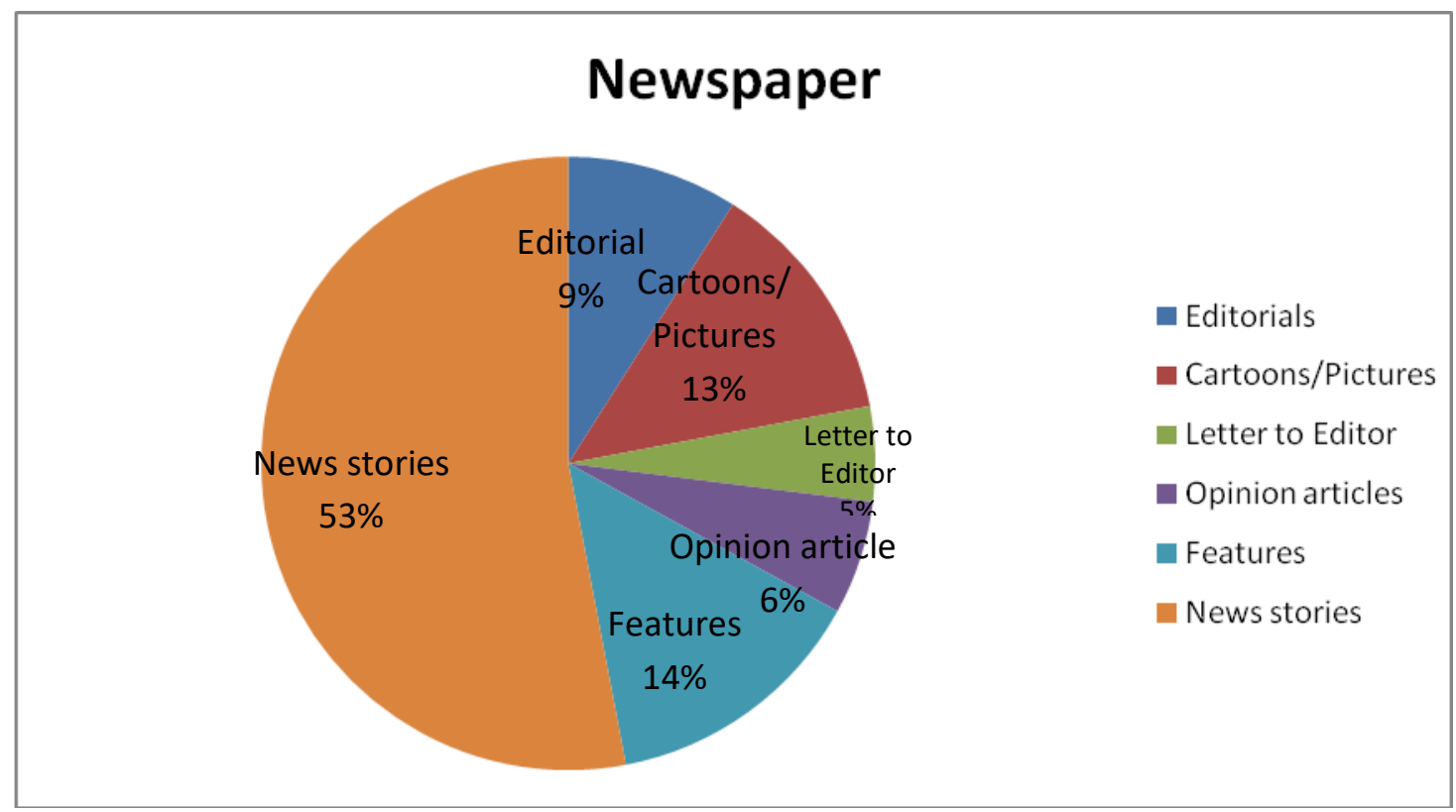

Table 2, (see appendix 2) shows that during the period under review, Vanguard newspaper had $70.6 \%$ favourable news; $14.7 \%$ unfavourable and 14.7 neutral news. This Day had $66.1 \%, 11.9 \%, 22 \%$ of favourable, unfavourable and neutral news respectively during the four month periods The Daily Sun carried $62.5 \%$ favourable news and $37.5 \%$ of unfavourable news, while Daily Sun did not have unfavourable stories on the issue. The Nations newspaper had $51.4 \%, 25.7 \%, 23 \%$ which represent favourable, unfavourable and neutral stories respectively. Thus, the table above shows that The Nations Newspaper had more favourable news on diplomatic face- off than other newspapers.

A pie chart showing direction of news reportage 


\section{Directionality of Reported Items}

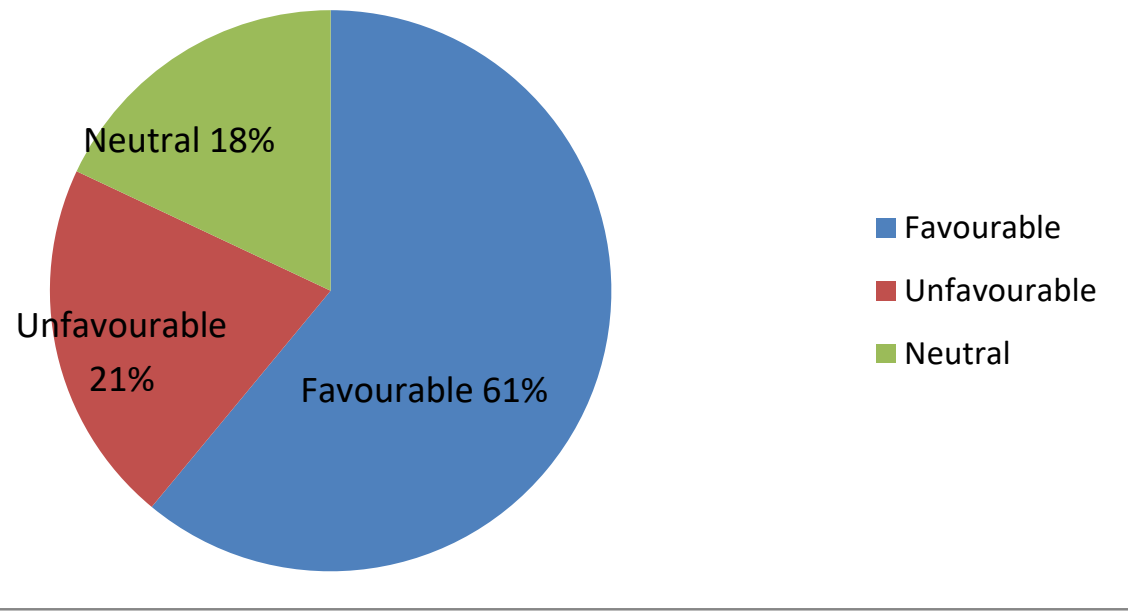

Table 3 (see appendix 3) shows that The Vanguard reported 33.9\% as front page stories, $53.6 \%$, and $12.5 \%$ as inside and back page story respectively. ThisDay reported $33.3 \%$ of front page stories, as well as $64.3 \%$ of inside page news, while $2.4 \%$ were back page stories. Daily Sun covered $41.2 \%, 52.9 \%$, and $5.9 \%$ of front page, inside page and back page stories respectively. Also $38.96 \%, 44.16 \%$ and $16.88 \%$ were of the stories covered by The Nation newspaper as front, inside and back pages respectively during the four months under review.

A pie chart of placement of story of the news paper.

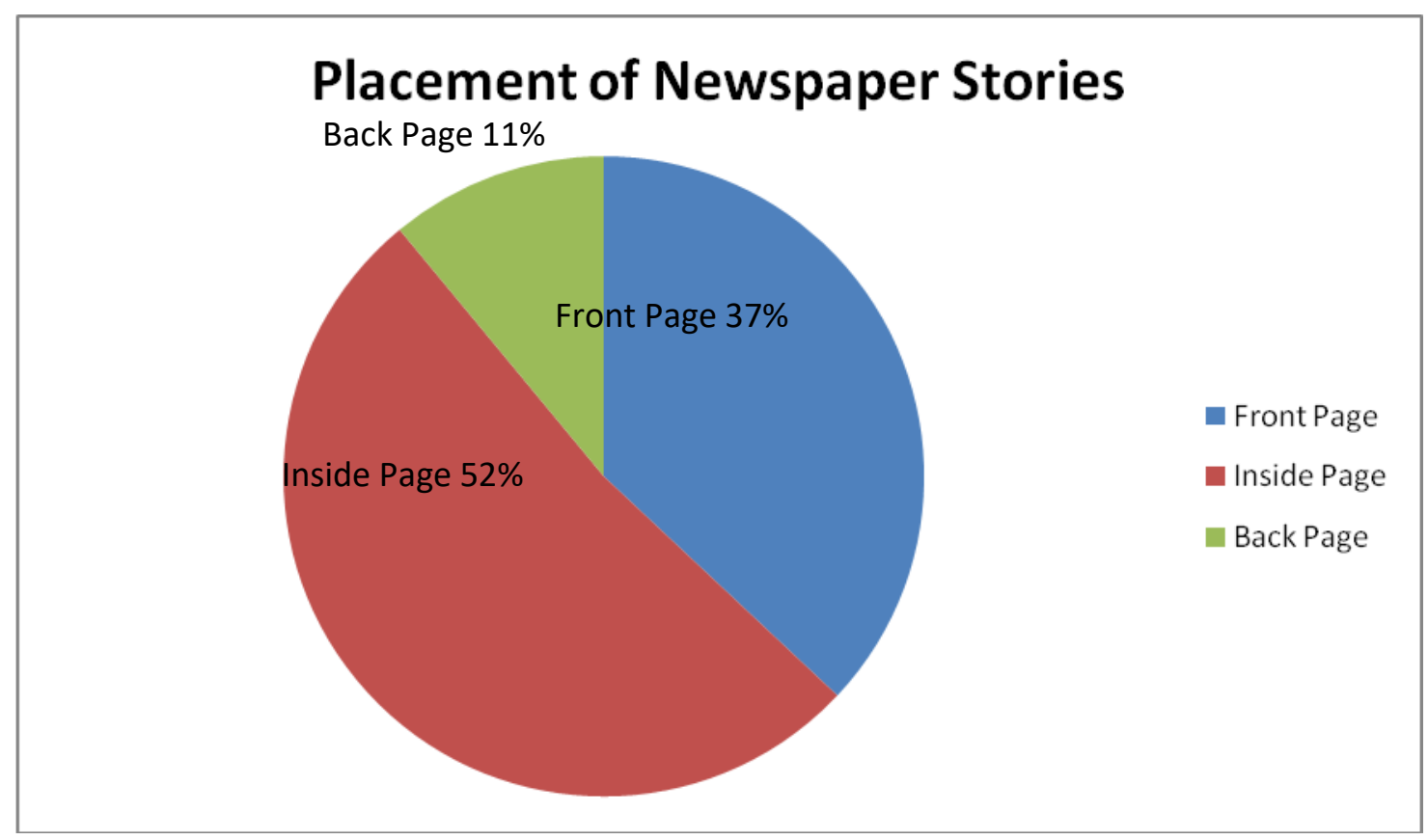


Table 4 (see appendix 4) shows the content categories of the items reported by the four Newspapers under review. The result shows that the items were centered on diplomatic relations between Nigerian and South Africa, reciprocity of the relationship with the two countries, yellow fever card, apology from South African government; Economic loss based on the face-off and Humiliation suffered by Nigerian and South African citizens deported as a result of the face - off. In all, the Nation newspaper carried the highest stories on diplomatic relations with $10.4 \%$, followed by $12.31 \%, 17.5 \%$, and $7.4 \%$ reported by Vanguard, Daily Sun, and ThisDay. Also the Vanguard newspaper had the highest stories on reciprocity $17.31 \%$, and Economic loss 23\%, apology 3.9\%, Yellow fever card 25\%, 13.7\% humiliation from the deportation. ThisDay also covered news on reciprocity, yellow card, apology, economic loss, and deportation and humiliation representing 12.9\%, 38.9\%, 5.6\%, 11.1\%, and $24.1 \%$ respectively. Daily Sun newspaper recorded the lowest reports on reciprocity 10\%, and economic loss $21.7 \%$ while The Nation newspaper covered least report relating to apologies $2.2 \%$. In all issues dealing with yellow fever card was the highest item with $29.7 \%$ while lowest item reported was on the apology $4.2 \%$.

A Pie Chart representation of content categories by the four newspapers in the four months under review

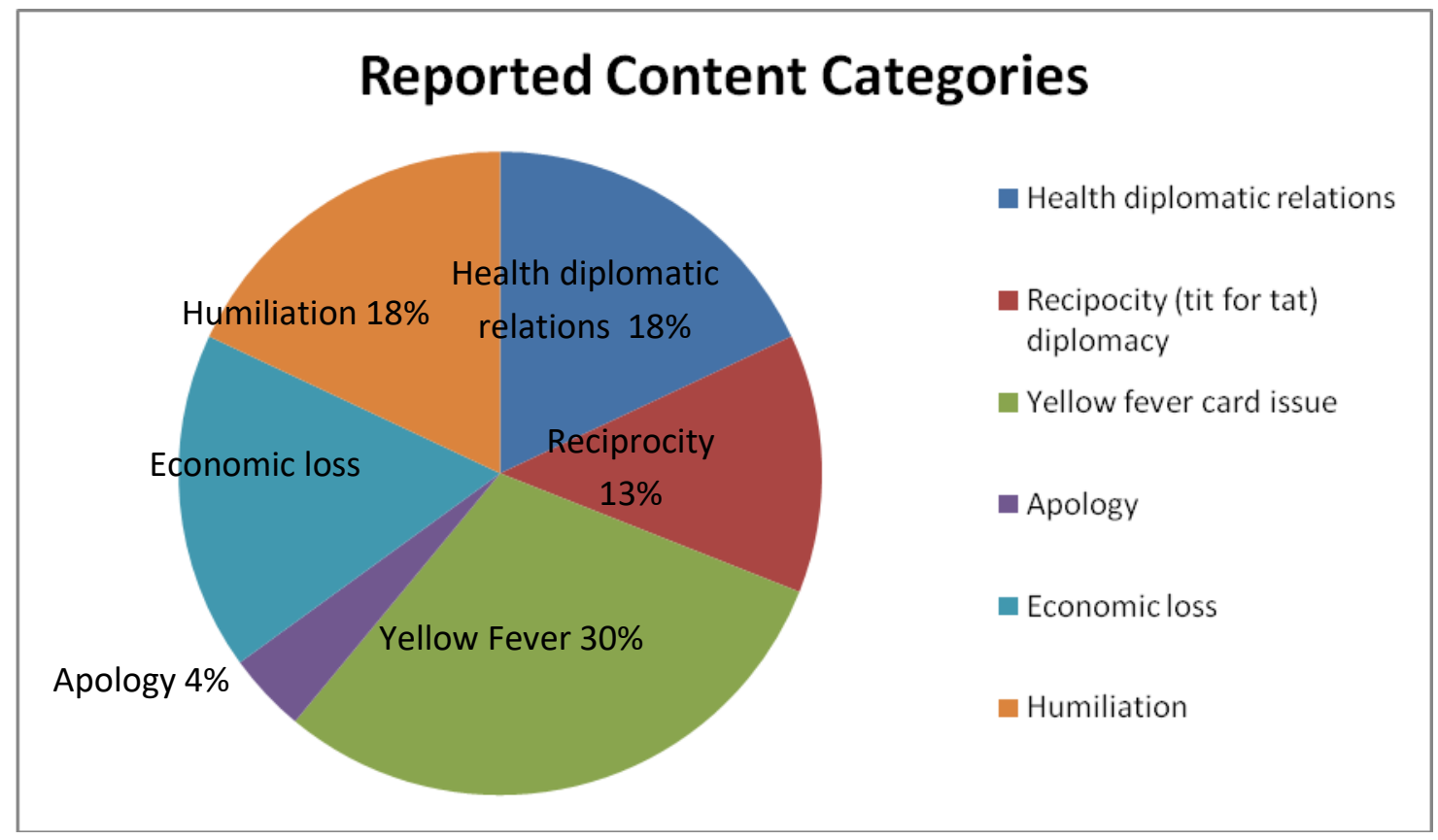

Tables 5 (see appendix 5) shows that reporters were the highest source of story on the issue with a total of $58.6 \%$ reported news during the months under review. Sources gotten from the 
Vanguard newspaper had 72.5\%,5\%,12.5\% and 10\% representing reporters, individuals, government, and corporate organizations. ThisDay newspaper had $52 \%$ of stories written by reporters, $2 \%$ individual contributors, followed by $30 \%$, and $16 \%$ of government and corporate bodies. Daily Sun sources of news were 33.6, 13\%, 43\%, and 10\% of reporters, individual contributors, government, and corporate bodies respectively. While The Nation which had the highest source of news 66.7 from reporters, $4.6 \%, 22.7 \%$ and $6 \%$ are individuals, government and corporate bodies sources respectively.

Pie Chart on Source of stories in the four Nigerian Newspapers

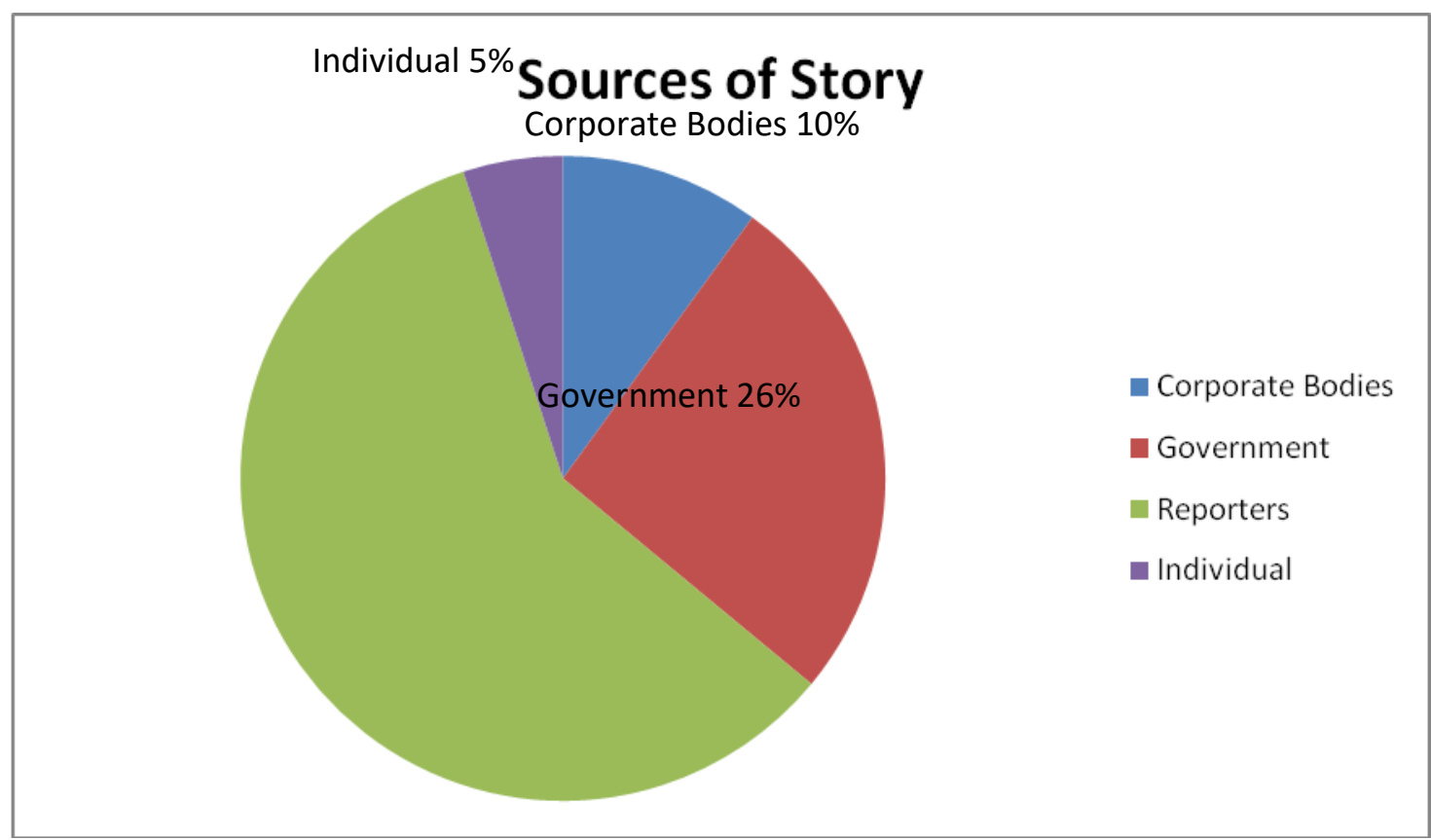

\section{Answering Research Questions}

RQ1: What is the extent of Nigerian press coverage of the yellow fever card face-off between Nigerian and South Africa?

The Nigerian press need be commended for their role in the diplomatic face-off between Nigeria and South Africa, because from the data gotten from table 3 the total number of news reported were 192 with front page, inside page, and back page representing $36.46 \%$, and $11.46 \%$ respectively. And if as much as $36.46 \%$ was given to front page stories, it shows that the issue was really of great importance and the press covered much of the stories on the fact that it was a major diplomatic face-off between the two countries. Also, news stories was given more priority with $52.69 \%$ and the highest sources of the news were from reporters 
$58.6 \%$ which shows that Nigerian reporters accorded great importance to the issue. It is a fact that for every diplomatic row, countries involved may suffer loss, which was the case with Nigeria threatening to come heavy on South Africa companies which had large stake in the Nigerian market.

Therefore, would not accept ill-treatment of the citizens. This is in line with tenets of citizen diplomacy (See Eze, 2009; Mbachu, 2009). These threats were well reported in Nigerian press. Nigerian - based - South African companies such as telecommunication giant- MTN, Standard Bank, and DSTV etc. were seen as the major loser, if the face-off had continued. ThisDay newspapers agree with the findings in table 4 about economic loss with the headline:"FG, its tit for tat with South Africa: "56 South Africans deported, plus South Africa companies under probe" (This Day, Wed, March 2012). Nigerian press gave extensive coverage of the issue as can be seen in the story types. Therefore, South Africa was made to apologize to Nigerian government.

Prior to this research, most people had the notion that Nigerian press do not cover foreign policy issues. But at the end of this study the information gathered and the analysis done have shown that the earlier thinking is quite on the contrary. The findings are in line with Rouke (1997) opinion that the press is not the preserve of the president or government officials but the protector of national interests.

From the findings of the study, it is evident that the press played a very tremendous role, as an effective and extensive medium for the coverage of the diplomatic face-off that ensued between the both countries. This is to say that the papers (national dailies) gave adequate coverage to the face-off with major news stories on the issue.

RQ2: What are the story placement, types and directionality of the press coverage of the face - off as reported in Nigerian press?

The papers had more stories on news than features, editorial opinion and cartoons (See table 1). The front page stories had a total of 70 stories $36.6 \%$ and inside pages of 100 stories $52.08 \%$. The highest numbers of stories were gotten from reporters which are $58 \%$ out of the 186 stories reported and the least which is $(5.4 \%)$ from individuals. Favourable stories were 
the highest with a total of $60.7 \%$, followed by unfavourable and neutral stories. On story type, news stories had the highest number $52.6 \%$, while personal opinion articles had the lowest $5.9 \%$. Also, on story placement, front page had $36.46 \%$, inside page had the highest with $52.8 \%$. while back page had the lowest $11.40 \%$ (see tables $1,2,3$ ).

RQ3: What are the content categories of the Yellow - Fever card face-off between Nigeria and South Africa?

The Yellow fever card which was the issue at stake was given good coverage with a total of $29.7 \%$ out of 100 of all news content. The effective press coverage of the Nigeria and South Africa diplomatic face can never be over emphasized, hence, the health implications (17.7\%), reciprocal relationship (13.5\%), apology from South Africa (4.2\%), economic loss based on the face - off and humiliation suffered by the citizens $(17.7 \%)$ were covered by the press (See table 4).

\section{Discussion of Findings (Qualitative Analysis)}

In this section, we tried to review some news items from the selected papers for the period of three months. This section involved a manifest content analysis of selected samples of reports from the selected papers. In a bold caption in The Vanguard, entitled: "South African begs Nigeria" (Friday march 9, 2012), the paper reports South African government as saying: "we apologize for this unfortunate incidence, and we hope this matter will not in any way affect our bilateral relations".

\section{On Apology from South African Government}

ThisDay in a story entitled: "Deportation: South Africa apologizes to Nigeria" dated (Friday March 9th, 2012) note "we apologize for this unfortunate incident and we hope that this matter will not in any way affect our bilateral relations". In an editorial with the titles headline: "hostage fiasco, South Africa apologizes" dated March 11th, 2012, entitles, The Nations newspaper notes that apology render by South Africa. Also, Daily Sun newspaper (Friday March 9, 2012) "South Africa surrenders" wrote that: "today I can confirm to you that I have received a letter from the South Africa Minister apologizing for the cause of action and deportation of 125 Nigerians last week. In the same newspaper the South African government promised to dispatch a special envoy as soon as possible to come and visit $\mathrm{Mr}$. 
President and to also convey the apology of the South African government. In fact in any direction you look at the stories above, they all lead to the resolution of the Nigeria/South African diplomatic row which represents favourable stories, as carried by the four respective papers used in this study. Hence, out of 191 stories studied, $116(60.7 \%)$ are favourable stories (see table 4).

\section{On Retaliation from Nigeria}

"Nigeria to hit adamant South Africa harder" was a front page caption written boldly by the Nation newspaper. Also, ThisDay (March 8, 2012, Vol. 7) wrote "South Africa should apologize today for the illegal deportation of 125 Nigerian passengers last Friday at the Oliver Tambo International Airport in Johannesburg or face tougher measures, officials said last night". Also, the Nation newspaper had the headline "Nigeria deports 28 South Africans as row deepens”, (Tuesday, March 6, 2012).

"We won't apologize to Nigeria-South Africa" was the headline on The Vanguard newspaper (Thursday March 8, 2012). The paper noted that South Africa "threatens to deport more Nigerians, said deportation of a Senator and others was not to embarrass FG, while Nigeria deports another 37 South Africans". Meanwhile a cartoon on page five of the paper had the caption, "FG faults South Africa claim on yellow fever card... deports 16 or South Africans".

We should therefore note that it is evident that the direction of the above news stories was not geared towards a good diplomatic relations between the both countries. Hence, the above stories bordering on retaliation can be seen as unfavourable towards resolving the diplomatic face-off between the two countries.

\section{On Peaceful Resolution of the Face-Off}

Neutral stories are those that did not support or fault reactions or actions from both countries over the issue, but sought for peaceful resolution of the crisis. The Nation newspaper of (Saturday March 17, 2012) had a story titled "Beyond the Tit for Tat Action Against South Africa" the paper noted that the diplomatic row was resolved after sometime and cordial relationship between the two countries was restored. In a headline on the editorial and commentary section of the same paper "page 10", titled "Re: Nigeria/South Africa and xenophobia" show that the stories were neutral stories. Nigeria-South African row won't 
affect ex-militants was the headline on the inside page of The Vanguard newspaper dated Thursday March 12, 2012. The paper noted: Thus "they are in school and there is no threat of deportation". The directions of these stories are pointing to the neutral angle of the face off. Hence, these are examples of stories that did not aim at escalating the face-off. In conclusion favourable stories had the highest reportage with $60.7 \%$ of all stories carried on the face-off between Nigeria and South Africa. This shows that Nigerians did not lose sight of the need to maintain good neighbourliness among African states.

\section{Conclusions}

We therefore, conclude that Nigerian press gave extensive but patriotic coverage of the yellow fever vaccination face - off between Nigeria and South Africa in line with the citizenship diplomacy ideology of the Nigerian government. However, the press was not unmindful of the political implication of the face-off, hence, it tried to balance national interest with African unity thereby emphasizing less on the bad relationship such incident is capable of generating among African sister states.

\section{Recommendations}

The researchers recommend that future face - off between Nigerian and South Africa should always be avoided where possible; and where such crises are inevitable as $n$ the yellow fever card and the constant xenophobic attacks by South Africans against Nigerians and other African nationals, the press should do everything to douse tension through neutral stories and unaised reportage of the issues involved. 


\section{References}

Agbu, O. (2009), Nigerian Foreign Policy under President Umaru Musa Yar'Adua. In Eze, O.C. (ed) Citizen Diplomacy. Lagos: NIIA.

Akinterinwa B.A., (2010), The Media in Nigeria's Foreign policy. Roles, Challenges and Prospects in Eze O.C. (ed) Beyond 50 years of Nigeria's Foreign policy Issues, Challenges and Prospects. Lagos: NIIA.

Atwood, L.E. \& Major, A.M (2000), Colonial Ties and News Coverage of the Third World in Uche, L.U. (ed) Worth-South Information Cultures Trends in Global Communication Research Paradigms. Lagos: Longman.

Carter, M.D. (1971) “An Introduction to Mass Communication: problem in Press and Broadcasting".

Dare, O. (1973) Analysis of the coverage of the 1973 middle East War in Nigerian Press. Unpublished B.A. Graduation Project, University of Lagos. Nigeria

Eze, O.C. (2009) Citizen Diplomacy, Bold Legal Perspective, Natural/International Dimension. In Eze, O.C. (ed) Citizen Diplomacy. Lagos: NIIA.

Hunt, G.T (2000),The image of Africa as Reflected by the Elite American Press in Uche, I.U (ed) North-South Information culture, Trends in Global Communication and Research Paradigm. Lagos Longman.

Maduekwe, O. (2009), Citizen Diplomacy. A Keynoth Address: As a Federal Republic Nigeria.

Mbachu, O. (2009) Citizen Diplomacy. The Challenges for Nigerian Defence and Security in the 21st Century in Eze, O.C. (ed) Citizen Diplomacy. Lagos: NIIA.

Meredith, M. (2011), The State of Africa. A History of the Continent Since Independence. London: Simon \& Schuser Ltd.

Momoh, T. (1988) Ethics Law of contempt and the press in Mohammed et al Mass Communication in Africa. Lagos: NIIT.

Mandela, N. (1995), Long walk to Freedom. New York: Little, Brown and Co.

Nwanze, I. (2008). Random Reflections Vol. 9. Port Harcourt: Heroes and Legends Ltd.

Nwuneli, O. \& Udoh, E. (1982), International News Coverage in Nigerian Newspapers Gazette Vol. 29.

Ogun, U. J. \& Olukosh, A. (2002), Nigeria's Economic Diplomacy: Some Contending Issues. In Ogwu, U.J. \& Adebayo, O.O. (eds). The Economic Diplomacy of the Nigerian State. Lagos: NIIA. 
Ogunsanwo, A (2009), Citizen Diplomacy Challenges for Nigeria's Foreign Policy. In Eze, O.C. (ed) Citizen Diplomacy. Lagos: NIIA.

Ogunsanwo, A. (2010) Regional Integration and International Corporation: Nigeria and the Economic Communities of West African States in Osita, C.E (ed) Reciprocity in International Relations Lagos: NIIA.

Okoye, M. (1995), “Embattled Man” Profiles in Social Adjustment. Enugu: Fourth Dimension Publishers.

Opubor, A.C. (1985), Mass Communication Policies and the Mass Media in Nigeria. Enugu: Fourth Dimension Publishers.

Sobourale, I. (1994), Nigeria Press Coverage of Natural Issues: A Paper Delivered at A three Day Workshop on Government-Press Relationship. Ottas Ogun State.

Uche, L. U (2000) Global Communication and the Challenges of Information Society: A Research Agenda. For the Faculty - First Century in Uche, L. U (ed) North - South Information Culture, Trends in Global Communication and Research Paradigms. Lagos: Longman.

Uche, L.U \& Ngumoha, U.N. (2000), Anglo-Nigerian Press Coverage of a Diplomatic Scandal. The Umaru Dikko Affair. In Uche, L.U. (ed) North - South Information Culture: Trends in Global Communication and Research Paradigms. Lagos: Longman.

Ugboajah, F.O. (1984) Foreign News Coverage in Nigeria Media. In George, G.\& Siefort, M. (eds) World Communication A handbook. Longman: New York.

\section{Newspaper Reports}

ThisDay, March 9, 2012

Daily Sun, March 8, 2012

Vanguard, March 9, 2012

Daily Sun, March 3, 2012

ThisDay, March 3, 2012

Daily Sun, March 4, 2012

ThisDay, March, 7, 2012

Vanguard, March 8, 2012

ThisDay, March 8, 2012

The Nation, March 6, 2012 
Vanguard, March 12, 2012

Business Day, March 10, 2012

\section{Appendix}

Table 1: Story type in the four newspapers from December to March, 2012

\begin{tabular}{|c|c|c|c|c|c|}
\hline $\begin{array}{c}\text { Story type } \\
\text { (Unit of } \\
\text { Analysis) }\end{array}$ & Vanguard & ThisDay & Daily Sun & The Nation & Total \\
\hline Editorial & $\begin{array}{l}3 \\
(11.3 \%)\end{array}$ & $\begin{array}{l}3 \\
(6.52 \%)\end{array}$ & $\begin{array}{l}5 \\
(18.52 \%)\end{array}$ & $\begin{array}{l}9 \\
(13.04 \%)\end{array}$ & $\begin{array}{l}17 \\
(9.14 \%)\end{array}$ \\
\hline News stories & $\begin{array}{l}27 \\
(61.4 \%)\end{array}$ & $\begin{array}{l}21 \\
(45.65 \%)\end{array}$ & $\begin{array}{l}10 \\
(37.04 \%)\end{array}$ & $\begin{array}{l}40 \\
(57.97 \%)\end{array}$ & $\begin{array}{l}98 \\
(52.69 \%)\end{array}$ \\
\hline Opinion articles & $\begin{array}{l}2 \\
(4.55 \%)\end{array}$ & $\begin{array}{l}5 \\
(10.87 \%)\end{array}$ & - & $\begin{array}{l}4 \\
(5.80 \%)\end{array}$ & $\begin{array}{l}11 \\
(5.91 \%)\end{array}$ \\
\hline Features & - & $\begin{array}{l}12 \\
(26.8 \%)\end{array}$ & $\begin{array}{l}8 \\
(29.63 \%)\end{array}$ & $\begin{array}{l}6 \\
(8.70 \%)\end{array}$ & $\begin{array}{l}26 \\
(13.98 \%)\end{array}$ \\
\hline Letter to editor & $\begin{array}{l}2 \\
(4.55 \%)\end{array}$ & $\begin{array}{l}1 \\
(2.17 \%)\end{array}$ & $\begin{array}{l}4 \\
(14.8 \%)\end{array}$ & $\begin{array}{l}3 \\
(4.35 \%)\end{array}$ & $\begin{array}{l}10 \\
(5.38 \%)\end{array}$ \\
\hline Cartons/picture & $\begin{array}{l}8 \\
(18.2 \%)\end{array}$ & $\begin{array}{l}4 \\
(8.70 \%)\end{array}$ & - & $\begin{array}{l}7 \\
(10.14 \%)\end{array}$ & $\begin{array}{l}24 \\
(12.90 \%)\end{array}$ \\
\hline Total & $\begin{array}{l}44 \\
100 \%\end{array}$ & $\begin{array}{l}46 \\
100 \%\end{array}$ & $\begin{array}{l}27 \\
100 \%\end{array}$ & $\begin{array}{l}69 \\
100 \%\end{array}$ & $\begin{array}{l}186 \\
100 \%\end{array}$ \\
\hline
\end{tabular}

Table 2: percentage distribution of the directionality of news reportage on the vaccination card face-off in the four Newspapers

\begin{tabular}{|c|c|c|c|c|c|}
\hline Direction & Vanguard & ThisDay & Daily Sun & The Nation & Total \\
\hline Favourable & $\begin{array}{c}24 \\
(70.6 \%)\end{array}$ & $\begin{array}{c}39 \\
(66.1 \%)\end{array}$ & $\begin{array}{c}15 \\
(62.5 \%)\end{array}$ & $\begin{array}{c}38 \\
(51.4 \%)\end{array}$ & $\begin{array}{c}116 \\
(60.7 \%)\end{array}$ \\
\hline $\begin{array}{c}\text { Unfavourab } \\
\text { le }\end{array}$ & $\begin{array}{c}5 \\
(14.7 \%)\end{array}$ & $\begin{array}{c}7 \\
(11.9 \%)\end{array}$ & $\begin{array}{c}9 \\
(37.5 \%)\end{array}$ & $\begin{array}{c}19 \\
(25.7 \%)\end{array}$ & $\begin{array}{c}40 \\
(20.9 \%)\end{array}$ \\
\hline Neutral & $\begin{array}{c}5 \\
(14.7 \%)\end{array}$ & $\begin{array}{c}13 \\
(22 \%)\end{array}$ & - & $\begin{array}{c}17 \\
(23 \%)\end{array}$ & $\begin{array}{c}35 \\
(18.3 \%)\end{array}$ \\
\hline Total & 34 & 59 & 24 & 74 & 119 \\
\hline
\end{tabular}




\begin{tabular}{|l|l|l|l|l|l|}
\hline & $100 \%$ & $100 \%$ & $100 \%$ & $100 \%$ & $100 \%$ \\
\hline
\end{tabular}

Table 3: Placement of stories from the four Nigerian newspapers under review.

\begin{tabular}{|l|l|l|l|l|l|}
\hline Placement & Vanguard & This Day & Daily Sun & The Nation & Total \\
\hline Front page & 19 & 14 & 7 & 30 & 70 \\
& $(33.9 \%)$ & $(33.3 \%)$ & $(41.2 \%)$ & $(38.96 \%)$ & $(36.46 \%)$ \\
\hline Inside page & 30 & 27 & 9 & 34 & 100 \\
& $(53.6 \%)$ & $(64.3 \%)$ & $(52.6 \%)$ & $(44.16 \%)$ & $(52.8 \%)$ \\
\hline Back page & 7 & 1 & 1 & 13 & 22 \\
& $(12.5 \%)$ & $(2.4 \%)$ & $(5.9 \%)$ & $(16.88 \%)$ & $(11.46 \%)$ \\
\hline Total & 56 & 42 & 17 & 77 & 192 \\
& $100 \%$ & $100 \%$ & $100 \%$ & $100 \%$ & $100 \%$ \\
\hline
\end{tabular}

Table 4 Distribution and analysis of content categories of reportage on the face - off by the Four National Newspapers on South African

\begin{tabular}{|c|c|c|c|c|c|}
\hline $\begin{array}{l}\text { Content } \\
\text { Categories }\end{array}$ & Vanguard & ThisDay & Daily Sun & The Nation & Total \\
\hline $\begin{array}{l}\text { Health } \\
\text { diplomatic } \\
\text { relations }\end{array}$ & $\begin{array}{l}9 \\
(17.31 \%)\end{array}$ & $\begin{array}{l}4 \\
(7.4 \%)\end{array}$ & $\begin{array}{l}7 \\
(17.5 \%)\end{array}$ & $\begin{array}{l}14 \\
(30.4 \%)\end{array}$ & $\begin{array}{l}34 \\
(17.7 \%)\end{array}$ \\
\hline $\begin{array}{l}\text { Reciprocity } \\
\text { (tit for tat) } \\
\text { diplomacy }\end{array}$ & $\begin{array}{l}9 \\
(17.31 \%)\end{array}$ & $\begin{array}{l}7 \\
(12.9 \%)\end{array}$ & $\begin{array}{l}4 \\
(10 \%)\end{array}$ & $\begin{array}{l}6 \\
(13.1 \%)\end{array}$ & $\begin{array}{l}26 \\
(13.5 \%)\end{array}$ \\
\hline $\begin{array}{l}\text { Yellow fearer } \\
\text { card issues }\end{array}$ & $\begin{array}{l}13 \\
(25 \%)\end{array}$ & $\begin{array}{l}21 \\
(38.9 \%)\end{array}$ & $\begin{array}{l}16 \\
(40 \%)\end{array}$ & $\begin{array}{l}7 \\
(15.2 \%)\end{array}$ & $\begin{array}{l}57 \\
(29.7 \%)\end{array}$ \\
\hline Apology & $\begin{array}{l}2 \\
(3.9 \%)\end{array}$ & $\begin{array}{l}3 \\
(5.6 \%)\end{array}$ & $\begin{array}{l}2 \\
(5 \%)\end{array}$ & $\begin{array}{l}1 \\
(2.2 \%)\end{array}$ & $\begin{array}{l}8 \\
(4.2 \%)\end{array}$ \\
\hline $\begin{array}{l}\text { Economic loss } \\
\text { that can be } \\
\text { caused by the } \\
\text { face-off }\end{array}$ & $\begin{array}{l}12 \\
(23 \%)\end{array}$ & $\begin{array}{l}6 \\
(11.1 \%)\end{array}$ & $\begin{array}{l}5 \\
(12.5 \%)\end{array}$ & $\begin{array}{l}10 \\
(21.7 \%)\end{array}$ & $\begin{array}{l}33 \\
(17.2 \%)\end{array}$ \\
\hline
\end{tabular}



Volume: 7 - Issue: 2 April - 2017

\begin{tabular}{|c|c|c|c|c|c|}
\hline $\begin{array}{l}\text { Humiliation } \\
\text { caused by the } \\
\text { deportation }\end{array}$ & $\begin{array}{l}7 \\
(31.5 \%)\end{array}$ & $\begin{array}{l}13 \\
(24.1 \%)\end{array}$ & $\begin{array}{l}6 \\
(15 \%)\end{array}$ & $\begin{array}{l}8 \\
(17.4 \%)\end{array}$ & $\begin{array}{l}34 \\
(17.7 \%)\end{array}$ \\
\hline Total & $\begin{array}{l}52 \\
100 \%\end{array}$ & $\begin{array}{l}54 \\
100 \%\end{array}$ & $\begin{array}{l}40 \\
100 \%\end{array}$ & $\begin{array}{l}46 \\
100 \%\end{array}$ & $\begin{array}{l}192 \\
100 \%\end{array}$ \\
\hline
\end{tabular}

Table 5: Distribution of the sources of the stories in the four newspapers under review

\begin{tabular}{|l|l|l|l|l|l|}
\hline Sources & Vanguard & This Day & Daily Sun & The Nation & Total \\
\hline Reporters & 29 & 26 & 10 & 44 & 109 \\
& $(72.5 \%)$ & $(52 \%)$ & $(33.6 \%)$ & $(66.7 \%)$ & $(58.6 \%)$ \\
\hline $\begin{array}{l}\text { Individual } \\
\text { Contributors }\end{array}$ & 2 & 1 & 4 & 3 & 10 \\
\hline Government & 5 & $(2 \%)$ & $(13 \%)$ & $(4.6 \%)$ & $(5.4 \%)$ \\
sources & $(12.5 \%)$ & $(30 \%)$ & $(43 \%)$ & $(22.7 \%)$ & $(25.8 \%)$ \\
\hline Corporate & 4 & 8 & 3 & 4 & 19 \\
bodies & $(10 \%)$ & $(16 \%)$ & $(10 \%)$ & $(6 \%)$ & $(10.2)$ \\
\hline Total & $\mathbf{4 0}$ & $\mathbf{5 0}$ & $\mathbf{3 0}$ & $\mathbf{6 6}$ & $\mathbf{1 8 6}$ \\
& $\mathbf{1 0 0 \%}$ & $\mathbf{1 0 0 \%}$ & $\mathbf{1 0 0 \%}$ & $\mathbf{1 0 0 \%}$ & $\mathbf{1 0 0 \%}$ \\
\hline
\end{tabular}

